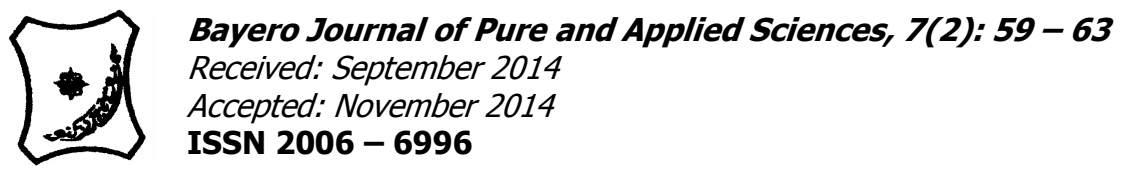

\title{
A SURVEY FOR HAEMO-PARASITE OF PIGS SLAUGHTERED IN JOS ABATTOIR PLATEAU STATE NIGERIA
}

\author{
$*^{1}$ Gagman, H. A., ${ }^{2}$ Ajayi, 0. O. and ${ }^{1}$ Yusuf, A.S. \\ ${ }^{1}$ Department of Biological Sciences, Bauchi State University Gadau, Bauchi State, Nigeria \\ ${ }^{2}$ Department of Zoology, University of Jos, Plateau State, Nigeria
}

*Correspondence author

\begin{abstract}
A survey for haemo-parasite of pigs slaughtered at the Jos Abattoir was carried out between May and November 2007, to determine the sex, age, breeds related incidence and possible risk factor(s) to the spread of infection using direct smear and staining technique. Out of the total of 532 pigs examined, 92(17.29\%) were positive for four genera of protozoan parasites with Trypanosoma spp accounting for 10(1.88\%), Babesia spp 23(4.32\%), Anaplasma spp 17(3.20\%), and Eperythrozoon spp 42(7.80\%). The female pigs haboured more of the blood parasites, 50(9.40\%), than the male pigs, $42(7.80 \%)$. The sex related rate of infection ranged from $1.5 \%-4.51 \%$ and from $0.75 \%-$ $3.38 \%$ for female and male pigs respectively. However, chi square analysis shows no significant differences in the sex related prevalence of haemo-parasites (p 0.05). The parasites established themselves more in the adult pigs, $79(18.8 \%)$ than in the young pigs 13(11.61\%). The infection rates ranged from $0.89 \%$ to $5.36 \%$ and from $2.14 \%$ to $8.57 \%$ for adult and young pigs respectively. Chi square analysis shows a significant difference in the infection rate between adult and young pigs ( $p$ 0.05). The blood parasites encountered in the different breeds of pigs were as follows: $87(17.51 \%)$ in the large white, $2(17.51 \%)$ in the large black and 2(15.00\%) in the mixed breed. There was no significant difference in the rates of infection among the different breeds of pigs (p.0.05). Generally there was low rate of occurrence $17.29 \%$ for haemo parasites of pigs slaughtered at the Jos Abattoir.
\end{abstract}

Keywords: Endemicity haemo-parasite, infection, pigs, rate,

\section{INTRODUCTION}

A parasite is an organism that has sustained contact with another organism to the detriment of the host organism, Weng, et al, (2005). Parasites are those organisms, which derived their means of survival from other animals called hosts and can deprive their host sometimes from surviving Hall, (1980). A parasite is any living organism (plant or animal) which lives inside or on the surface of another organism (the host) and from which it gains it food supply and other means of lively hood Henderson, (1990).

Parasites of pigs cause major economic loss globally to pig and pork industries and farming community as a consequence of reduced feed conversion and weight gains. Boes et al, (2000), Joaching and Dulmar, (2001). Hoemo-parasites of pigs are endemic and prevalent within the tropics and subtropics Levine, (1985). The most prevalent of blood parasites of pigs include the following: Tryponosoma congelence, the most common among the pigs in the tropics, Trypanosoma species, Eperythrozoon pervum, Eperythrozoon suis, Babesia trautmani, Babesia perroncitoi, Anaplasma species Finelle, (1973) and Levine, (1985).

Pigs become infected with haemo-parasites due to the bite of blood sucking arthropods such as tsetseflies, ticks, lice etc Weng et al, (2005). Eperythrozoon, Rikettsiae, Theileria, and Babesia species are transmitted by louse and ticks Ngole et al. (2001), Bell-Sakyi et al. (2004). The development of parasites eminently depended on the suitable tropical environment. Robert and Rodric, (2005). The objectives of this research are to determine sex, age, and breed related rate of infection with haemoparasite of pigs slaughtered at the Jos Abattoir and also to determine the possible risk factor to the spread of the epidemic.

\section{MATERIALS AND METHODS}

Study Site

Collection of samples was carried out from pigs slaughtered at Jos Abattoir. Jos Abattoir is located in Jos South Local Government Area of Plateau State (Figure 1). Jos South Local Government Area is located south of Jos North between longitude $8^{0} 48^{\prime} \mathrm{W}$ and latitude $9^{0} 94^{\prime} \mathrm{N}$., in North Central Geo-political Zone of Nigeria. The headquarters is at Bukuru, which is about 15 kilometers from Jos town, the capital of Plateau State. The area is about 1,250 metres above sea level. The abattoir is a processing unit for pork hence provides job opportunity for butchers and markets for farmers (Animal breeders).

\section{Collection of Blood Sample}

Blood samples were collected according to method demonstrated by Adejinmi et al. (2004) blood samples were collected from the jugular veins of each pig with a sterile hypodermic needle and syringe.

About $2 \mathrm{ml}$ of blood was collected from each animal into bottles containing ethylenediamine tetra-acetic acid (EDTA) as anticoagulant. 


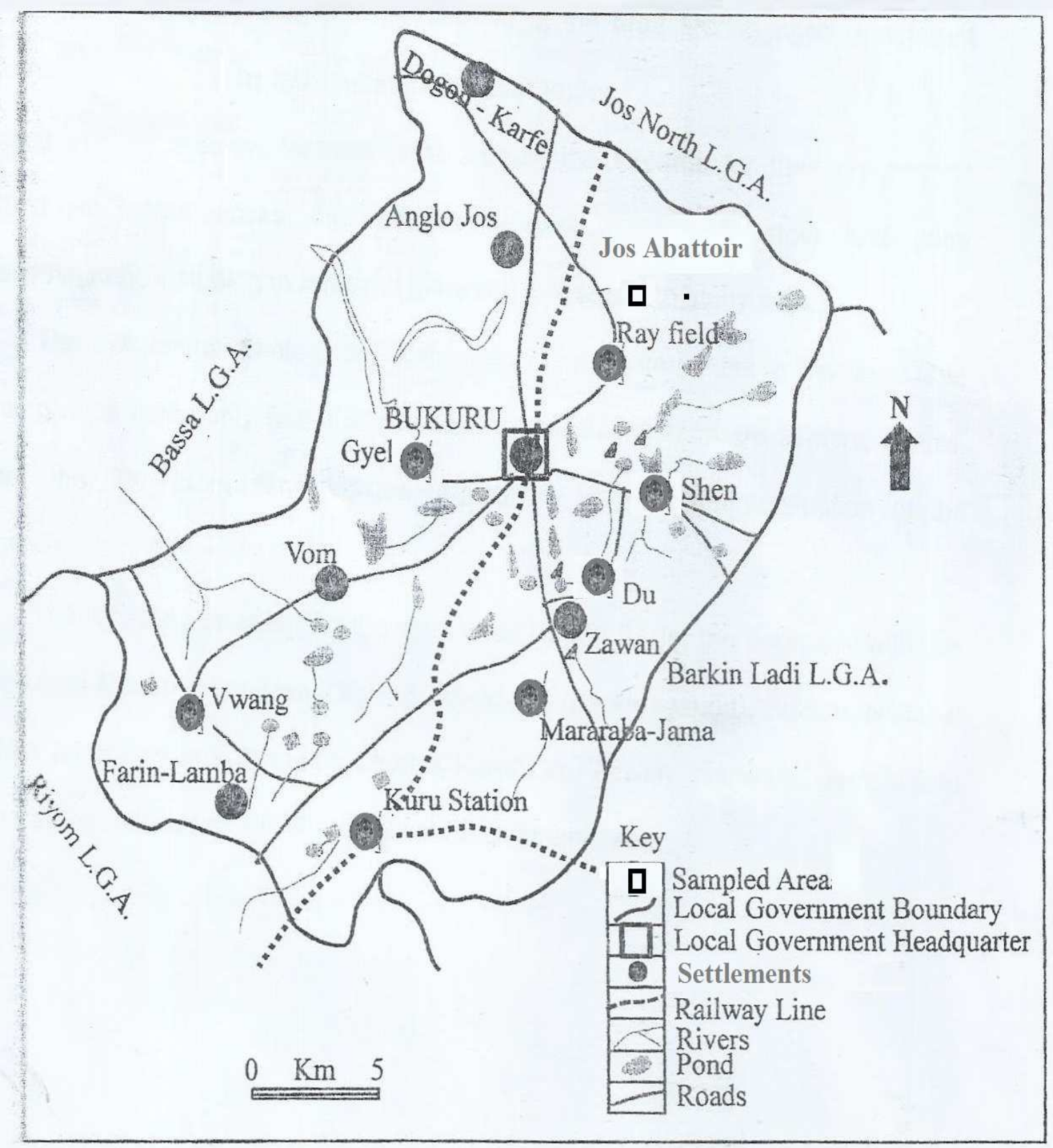

Map of Jos South Local Government showing Sample Area

Source: Jos South Local Government Council

Figure 1: Map of Jos South Local Government Area indicating the location of the abattoir 


\section{Analysis and Examination of Blood Sample Preparation of Thick Blood Film}

Thick blood film was prepared using Standard Method described by Adams et al, (1977), Cheesbrough (2000). A blood sample was drop on a clean greasefree glass slide and made into a thick circular film, waved in the air and allowed to dry. It was fixed in $70 \%$ methanol for 3 minutes and air dried. It was stained with Giemsa stain for 30 minutes, washed under tap water till the blue Giemsa colour disappeared. The slide was air-dried and examining under the oil immersion objective of the microscope for the presence of haemo-parasites. The parasites were identified using the keys adopted by Chandler (1961) and Cheesbrough (2000).

\section{Preparation of Thin Blood Film}

A drop of blood was placed on one end of a greasefree glass slide. Another slide with a narrower edge was held at $45^{\circ}$ to the drop of blood until the blood spread at its margin. The slide was steadily and rapidly moved backwards to make a thin film. The film was air-dried and fixed in 70\% methanol for about 2 minutes, stained with Giemsa's stain for 30 minutes. The slide was washed under tap water, air-dried and examined under the oil immersion objective of the microscope for the presence of haemo-parasites adopted by Cheesbrough, (2000), Chandhri and Goupte (2003). The parasites where identified using keys adopted by Cheesbrough, (2000) Chandhri and Goupte, (2003)

\section{$>$ Statistical Analysis}

A Pearson's chi-square test was used to test a correlation between occurrence of haemo-parasites and age, sex and breeds of pigs.

\section{RESULTS}

Table 1 shows the overall rate of infection with haemo-parasites of pigs slaughtered at the Jos Abattoir. Four species of haemo-parasite were identified. These include Trypanosoma $s p$, Babesia $s p$, Anaplasma $s p$ and Eperythrozoon sp. Eperythrozoon $s p$ has the highest infection rate of $7.89 \%$ followed by Babesia sp $4.32 \%$ and Anaplasma sp $3.20 \%$ Trypanosoma $s p$ recorded the lowest rate of $1.88 \%$. The sex related prevalence of haemo-parasites of pigs is shown in Table 2. The parasites established themselves more in males $17.95 \%$ than in females $16.78 \%$. Eporythrozoon $s p$ established themselves more than any of the parasites in both females and males $4.51 \%$ and $3.38 \%$ respectively. This is followed by Babesia $s p 4.03 \%$ and $2.07 \%$, Anaplasma $s p$ $1.50 \%$ and $1.69 \%$, and Trypanosoma $s p$, recorded the least rate of $2.01 \%$ and $0.75 \%$ in both females and males respectively. Chi square analysis revealed no significant difference in the infection rate between females and males pigs at $(p<0.05)$.

The age related rate of infection with haemoparasites is shown in Table 3. The blood parasites encountered more $18.8 \%$ in adult than $11.61 \%$ in young pigs. Epenythrozoon $s p$ recorded the highest prevalence rate of $8.57 \%$ and $5.36 \%$ for both adult and young pigs respectively. Chi square analysis revealed significant difference in the infection rate between the adult and young pigs $(p<0.05)$.

The rate of infection with haemo-parasites among the various breeds of pigs is recorded in Table 4. The parasites were more encountered among the large white at a rate of $17.51 \%$ followed by the mixed breeds $15.00 \%$ and the least infection rate was recorded among the large black $13.33 \%$. chi square analysis revealed that, there was no significant difference in the rate of infection with haemoparasites among the different breeds of pigs $(p<0.05)$.

Table 1: Overall rate of infection with haemo-parasites of pigs slaughtered at the Jos Abattoir

\begin{tabular}{lllll}
\hline S/N & Parasite & No. of pig examined & No infected & Percentage \\
\hline 1 & Trypanosoma spp & 532 & 10 & 1.88 \\
2 & Babesia spp & 532 & 23 & 4.32 \\
3 & Anaplasma spp & 532 & 17 & 3.20 \\
4 & Eperythrozoon & 532 & 42 & 7.89 \\
5 & Total & 532 & 92 & 17.29 \\
\hline
\end{tabular}

Table 2: Sex related prevalence of haemo-parasite of pigs slaughtered at the Jos Abattoir.

\begin{tabular}{|c|c|c|c|c|c|c|}
\hline \multicolumn{2}{|c|}{ Parasite type } & \multirow{2}{*}{$\begin{array}{l}\text { Trypanosoma } \\
\text { spp } \\
\text { No infected } \\
(\%)\end{array}$} & \multirow{2}{*}{$\begin{array}{l}\text { Babesia } \\
\text { spp } \\
\text { No } \\
\text { infected } \\
(\%)\end{array}$} & \multirow{2}{*}{$\begin{array}{l}\text { Anaplasma } \\
\text { spp } \\
\text { No infected } \\
(\%)\end{array}$} & \multirow{2}{*}{$\begin{array}{l}\text { Eperythrozoon } \\
\text { No infected (\%) }\end{array}$} & \multirow[b]{2}{*}{$\begin{array}{l}\text { Total } \\
\text { infected } \\
(\%)\end{array}$} \\
\hline Sex & $\begin{array}{l}\text { No of Pig } \\
\text { Examined }\end{array}$ & & & & & \\
\hline Sows & 298 & $6(2.01)$ & $12(4.03)$ & $8(1.50)$ & $24(451)$ & $50(16.78)$ \\
\hline Hogs/boars & 234 & $4(0.75)$ & $11(2.07)$ & $9(1.69)$ & $18(3.38)$ & $42(17.95)$ \\
\hline
\end{tabular}


Table 3: Age related prevalence of heamo-parasites of pigs slaughtered at Jos Abattoir.

\begin{tabular}{|c|c|c|c|c|c|c|}
\hline \multicolumn{2}{|l|}{ Parasite type } & \multirow{2}{*}{$\begin{array}{l}\text { Trypanosoma } \\
\text { spp } \\
\text { No infected } \\
(\%)\end{array}$} & \multirow{2}{*}{$\begin{array}{l}\text { Babesia } \\
\text { spp } \\
\text { No } \\
\text { infected } \\
(\%)\end{array}$} & \multirow{2}{*}{$\begin{array}{l}\text { Anaplasma } \\
\text { spp } \\
\text { No infected } \\
(\%)\end{array}$} & \multicolumn{2}{|c|}{ Eperythrozoon } \\
\hline Age & $\begin{array}{l}\text { No of Pig } \\
\text { Examined }\end{array}$ & & & & $\begin{array}{l}\text { No infected } \\
(\%)\end{array}$ & $\begin{array}{l}\text { Total } \\
\text { infected } \\
(\%)\end{array}$ \\
\hline Piglet(young) & 112 & $1(0.8$ & $4(3.50)$ & $2(1.79)$ & $6(5.36)$ & $13(11.61)$ \\
\hline Adult & 420 & $9(2.14)$ & $19(4.52)$ & $15(3.57)$ & $36(8.57)$ & $79(18.8)$ \\
\hline
\end{tabular}

Table 4: Breeds related prevalence of haemo-parasites of pigs slaughtered at Jos Abatoir.

\begin{tabular}{lllllll}
\hline Parasite type & & $\begin{array}{l}\text { Trypanosoma } \\
\text { spp } \\
\text { No infected } \\
\text { Breed }\end{array}$ & $\begin{array}{l}\text { No of Pig } \\
\text { Examined }\end{array}$ & $\begin{array}{l}\text { Babesia } \\
\text { spp } \\
\text { No } \\
\text { infected } \\
(\%)\end{array}$ & $\begin{array}{l}\text { Anaplasma } \\
\text { spp } \\
\text { No infected } \\
(\%)\end{array}$ & Eperythrozoon \\
& & & $21(4.23)$ & $16(3.22)$ & $41(8.25)$ & $\begin{array}{l}\text { No infected (\%) } \\
\text { Total } \\
\text { infected } \\
(\%)\end{array}$ \\
\hline Large white & 497 & $9(1.81)$ & $1(6.67)$ & $0(0.00)$ & $0(0.00)$ & $2(13.33)$ \\
Large black & 15 & $1(6.67)$ & $0(0.00)$ & $1(5.00)$ & $1(5.00)$ & $2(15.00)$ \\
Mixed breed & 20 & $1(5.00)$ & & & & \\
\hline
\end{tabular}

\section{DISCUSSION}

Four genera of haemo-parasites were encountered during the investigation, namely Trypanosoma, Babesia Anaplasma, and Eperythrozoon. This is consistent with the findings of Okon (1976), Adejinmi et $a l$, (2001) there was no significance difference in the Sex, and breeds related rate of infection with Haemo-parasites in the Pigs. However, there is significant difference in the infection rate between young and adult pigs. This difference may not be unconnected with the free range system of rearing of pigs where the pigs roam about. In this case the adult pigs move far away from their pen house than the young pigs, hence adult are exposed to blood sucking insects which are vectors of haemo-parasite than the young pigs. Another reason could be that, most of the young once are still breast feeding or newly wean, hence have more immunity than their adult's counterparts.

The infection rate of haemo-parasite is generally low. This could be due to high fats deposit in the subcutaneous tissue layer of the pigs which make it difficult for the insect vectors of haemo-parasite of pigs to penetrate through the skin in their biting and sucking mode of feeding.

$$
\text { Eperythrozoon Suis causes }
$$

eperythromozoonosis, a haemotrophic diseased in swine. The disease is clinically characterized by anaenia, jaundice, marked palness of the mucous, presence of blood of water aspect, delay of growth and increase mortality in feeder pigs Hoelzie et al, (2003).

$17.29 \%$ of the 532 pigs sampled were found to be infected with the four genera of the haemo-parasites this is contrary to the findings of Dipeolu et al, (1982) who reported that $81 \%$ of local pigs were positive for blood parasites while $41 \%$ exotic pigs had haemoparasites in Ibadan. The differences in this study and that of Dipeolu et at, (1982) may be due to the fact that the pigs are exposed to more insects vectors of blood parasites in the western part of Nigeria than in the north also from 1981 to 2007 there is great improvement in veterinary medical care, which greatly reduces infections rates of haemo-parasites. Babesia of swine causes babesiosis. Piglets and adults swine are equally sausceptable. In the acute stage of disease, there is fever, anemia, haemoglobunaria, Jaundice, and Oedema of the affected parts. Pregnant sows may abort and mortality may reach $50 \%$ Soulsby, (1982).

There is need for appropriate treatment against these parasites in infected pigs. This when carried out will improve the living standard of the owners since pigs have great economic potentials among the rearers in Jos. Also the treatment is important to avoid transmission of zoonoses among the pork eaters and sometimes even the none eaters as they interact with the park eaters. A free ranged system of animal husbandry should be discouraged among pig farmers. This should be backed up by legislation and penalties for defaulters. These will minimize exposure of pigs to parasites. Porks should be thoroughly prepared to get rid of the parasite (Adults, Eggs, Cysts) before eating.

\section{CONCLUSION}

The haemo-parasites recorded in this study are Trypanosoma, Babesia, Anaplasma and Eperythrozoon species which occurred among $92(17.29 \%)$ out of 532. Though the infection rate in this finding is low as compared to previous researches, the infection with parasites is endemic. Some of the parasites constitute known zoonoses for man and may be involved in the epizootiology of a number of parasites that affect other domestic species in the area Fabiyi, (1979). The present result should therefore, be of interest to veterinarians, pig farmers and health workers. 


\section{REFERENCES}

Adams K. M. G, Paul, J. and Zama V. (1977). Medical and Veterinary protozoology, an illustrated guide, Revised edition, published by churchil living stone Edinburg and London pp $32-48$.

Adejinmi, J. O et al (2004). Studies on the blood parasite of sheep in Ibadan Nigeria. African Journal of Biomedical Research. 7: 41 - 43.

Bell-Sakyi L., Koney E. BM, et al (2004), Ehrlichia ruminartium seroprevalence in domestic ruminants in Ghana. Longitudinal Survey in the Greater Region. Veterinary Microbiology 100: $175-188$.

Boes, J., Willingham, A. L. Nansen, P. (2000). Prevalence and distribution of pig helminthes in Dongtin region China. Journal of Helminthology, 74: 45-52.

Chandhri S. S. Goupte S. K (2003), Manual of General Veterinary Parasitology, First edition, International book distributing co. pp 19 48.

Chandler, A. C., Read, C. P. (1961). Introduction to Parasitology. John Wiley and sons Inc. London $10^{\text {th }}$ edition pp $140-145$.

Cheesbrough M. (2000). District laboratory practice in tropical countries, part 2. Press sundicate of the University of Cambridge U.K Pp 320 321.

Dipeolu, O. O. Majaro, O. M and Akinboade, O. A. (1982), Studies on blood parasites of pigs in Ibadan. Journal of Veterinary Parasitology 10: $87-90$.

Fabiyi, J. P. (1979). Helminths of the Pig on Jos Plateau, Nigeria: relative prevalence, abundance and economic significance; Journal of Helminthology 53: 65-71.

Finelle, (1973), African Animal Trypanosomiasis. World Animal Review 7: $1-6$ and 8: $24-27$.
Hall, T. B. (1980). Diseases and parasites of Livestock in the Tropics. Wing Tai Cheung printing Company Limited Hong Kong. Pp 192-214.

Henderson D. C (1990), The Veterinary sheep farmers. Farming press books Pp 477

Hoelzle, et al (2003), Development of diagnostic PCR assay based on novel DNA sequence for the detection of Myeoplasma suis (Eperythrozoon suis) in porcine blood Veterinary Microbiology 93: 185 - 199.

Joaching, A., Dulmar, N. (2001). Occurrence of helminthes in the pig fattening units with different management system in Northern Germany. Veterinary Parasitology. 9: 135146.

Levine N. D. (1985) Veterinary Protozoology Lowa state University press, pp. $34-39$.

Ngole, I. U, Ndamukong K. J. N and Mbuh J. U (2001). Intestinal Parasites and Blood Picture of Dwarf Forest Goats Slaughtered in Buea South West, Cameroon. Bulleting of Animal Health and Production in Africa. 49: 134 138.

Okon E. D. (1976). Blood parasites of local pigs in Ibadan Nigeria. Tropical Animal Health and production 8: $96-97$.

Robert, M. C. and Rodric, C. I. (2005) Common internal parasites of swine, University of Missouri Mu Extension. 30: 1-7.

Souslsby, E. J. L. (1982), Helminths, arthropods and protozoa of domesticated animals Bailerier Tindel and cox limited London seventh edition pp $517-755$.

Weng, Y. B. Hu, Y. J., Li, Y., Li, B.S., Lin, D. H., Xie, Gasser, R. B., Zhu, X. Q. (2005). Survey of intestinal parasites of pigs from intensive farms in Guangdong province, people's Republic of China. Journal of Veterinary Parasitology. 127: 333-336. 